IRSH 5 I (2006), Supplement, pp. 85-I09 DOI: I0.10I7/So020859006002628 (C) 2006 Internationaal Instituut voor Sociale Geschiedenis

\title{
On the Move: Circulating Labor in Pre-Colonial, Colonial, and Post-Colonial India*
}

\author{
IAN J. KER R
}

In 1770 a British official in Madras observed groups composed of men, women, and children who formed "a kind of travelling community of their own under a species of Government peculiar to themselves, with laws and customs which they follow and observe wherever they go". These itinerant, coveted groups of earth and stone workers - "even courted by Princes" - circulated from worksite to worksite where they dug tanks (small reservoirs), ditches, and wells, and built roads and fortifications. They lived close to their worksites in "temporary hutts which they throw up for the occasion, and always chuse a spot distinct from any village, wandering from one place to another as is most convenient". ${ }^{2}$

Circulating labor (a phrase that captures frequent movement better than migrant labor), with a particular but not singular emphasis on construction labor, provides the subject matter of this paper. ${ }^{3}$ The paper seeks, spatially, to identify the substantial, pan-Indian presence of circulating workers; temporally, to establish the presence of many such workers in the pre-colonial, early colonial (e.g. I770 Madras), high colonial (later nineteenth/early twentieth century) and post-colonial periods; and conceptually, to explore how we might situate these workers within the history of India.

* A draft of this paper was presented at the International Workshop, "Towards Global Labour History: New Comparisons", at the V.V. Giri National Labour Institute, New Delhi, November 2005 . I am grateful to those whose efforts made the conference a success and my attendance possible. I benefited from helpful critics at the Delhi conference, and from an editor of this collection, Rana Behal. Prasannan Parthasarathi, Niels Brimnes, Adapa Satyanarayana, and Ian Petrie kindly identified useful sources. Katy Hunt provided invaluable assistance. A Social Science and Humanities Research Council (Canada) Standard Research Grant supported my research.

I. British Library, Oriental and India Office Collections [hereafter OIOC], George Paterson, MS Eur.E379/2, "The Paterson Diaries," entry dated 23 November 1770. The diaries cover the years I 769-1775. Paterson, a keen observer, was the secretary to successive East India Company naval commanders-in-chief.

2. OIOC, Paterson Diaries, 23 November 1770.

3. Because migrant labor and itinerant labor are commonly used, I deploy both as rough synonyms for circulating labor. However, I do suggest that migrant labor is not the best label for many of the groups discussed in this paper. 


\section{CONCEPTUAL CONSIDERATIONS}

A pioneering study of migrant labor in Europe, I600-I900, stated that "little serious attention" had been paid to migrant workers despite their importance to European labor markets. ${ }^{4}$ Various obstacles, the author noted, had hampered the study of migratory labor: one was the fragmentation of migration history into a number of sub-specialties - of which labor migration is one - that weakened the search for more inclusive, integrated understandings of human mobility; another was the limited integration of the recent findings of migration history into more general expressions of historical understanding. Migration history must emerge fully from its specialized ghetto if it is to enrich the more general social, cultural, and economic narratives. 5 The movement across space in the search for employment is the normal condition under which large numbers of people lead their lives. And, on the other side of the coin, many demands for labor power could not have been met without the presence of migrant labor - a situation as true in the twenty-first century as in the preceding centuries.

A distinct sub-grouping within migratory labor is particularly ignored in the European literature. These are the itinerant workers who - like those in Madras in 1770 - practiced ambulatory occupations (including trade and transportation), and who traveled in family groups. ${ }^{6}$ Research on this "striking case of migrants [...] has been marginal at best". 7 The same groups, moreover, were marginalized, even criminalized, by the authorities and local inhabitants in the areas through which they moved. They became the quintessential social outsiders, the feared, despised or degraded "others" despite their importance to local economies. Those labeled gypsies were the most severely affected. The historiography has reflected societies' treatment of these groups: their imputed criminality, marginality, and poverty - their "stigmatization" - has preoccupied scholars to the detriment of understanding their important economic functions. ${ }^{8}$

4. Jan Lucassen, Migrant Labour in Europe 1600-1900: The Drift to the North Sea, Donald A. Bloch (tr.) (London, I987), p. I.

5. My brief summary of the European literature is derived from Jan Lucassen and Leo Lucassen, "Migration, Migration History, History: Old Paradigms and New Perspectives", in Jan Lucassen and Leo Lucassen (eds), Migration, Migration History, History: Old Paradigms and New Perspectives (Berne, 1997), pp. 9-38. "State-centrism", "modernization-centrism", and "Euro- or Atlantocentrism" are terms used by the Lucassens.

6. Leo Lucassen, "A Blind Spot: Migratory and Travelling Groups in Western European Historiography", International Review of Social History, 38, (1993), pp. 209-235, 210 . This article is reprinted in Leo Lucassen, Wim Willems, and Annemarie Cottaar, Gypsies and Other Itinerant Groups: A Socio-Historical Approach (Basingstoke, I998), pp. I35-I 52.

7. Leo Lucassen, "Eternal Vagrants? State Formation, Migration, and Travelling Groups in Western-Europe, I350-I9I4", in Lucassen and Lucassen, Migration, Migration History, History, pp. 225-251, 225 .

8. Ibid., pp. $225-227$. 
Thirdly, a set of classificatory concepts - expressed in different historiographical streams and therefore contributory to disciplinary fragmentation - has had a negative impact on the history of migratory labor. These include distinctions between free and unfree migrations, labor migrants versus refugees, the movements of peoples versus the processes whereby migrants become settled in new locations (with the latter often focussing on issues of assimilation, integration, racism and ethnicity), and finally a powerful set of political, temporal and geographical predispositions that limit the quest for more broadly-based, integrated understandings.

The latter include, firstly, "state-centrism" in which migration is seen to be that which occurs across state borders triggered largely by state action and/or constrained or encouraged by state policies. This shunts to the sidelines "voluntary" labor migration, be it within or across state borders. A second predisposition, "modernization-centrism", leads to a focus on migratory labor in industrializing or post-industrial Europe; in short on the period during which the processes of modernization (defined in a certain way) took hold. Since this was also a period of intensified state building, "state-centrism" is intensified, and the connection of migration with more recent and disruptive (much of the migration literature stresses uprooting) socio-economic changes is reinforced. Thus, earlier manifestations of migration in proto-industrial, predominantly agrarian societies with pre-industrial forms of capitalism and different political structures (e.g. city-states, the segmentary states of earlier south India, or territorially vast empires) receive less attention.

Thirdly, there is "Euro-" or "Atlantocentrism", leading to an emphasis on studies of migration in western Europe or across the Atlantic, with the latter encompassing the "voluntary" migrations to North America and parts of Latin America (e.g. Italians to Argentina), and the African slave trade to North America, the West Indies, and Brazil. This third predisposition has lost much of its restraining power in recent years but more spatially encompassing approaches to migration continue to be influenced by state-centric and modernization-centric analyses. ${ }^{9}$

Readers familiar with the literature on migration and migratory labor in the Indian context will recognize the presence of many of the characteristics glossed above. However, this is not a bibliographical essay and space does not permit extensive reference to the good studies that are available. Suffice it to say that fragmentation and inadequate integration into general histories is present. To take but one example: much writing about migration can be found in the diaspora literature which often focuses on Atlantocentrism" and the continued force of "state-centrism". 
cultural factors; the same migratory streams studied from economic perspectives often display little familiarity with the diaspora literature, and vice versa. State-centrism, too, is a pronounced predisposition as is modernization-centrism.

The overall result has been a good but skewed understanding of certain categories of circulating labor in colonial and post-colonial India; little understanding of circulating labor in pre-colonial India; virtually no study of the long-term presence of forms of itinerant labor established in the precolonial period and continuously present throughout the colonial and post-colonial eras; and, therefore, the near absence from the literature of the large bodies of workers, including construction workers, who populated those ignored worlds of labor. Indeed, if we did not have the distinguished writings of Jan Bremen - writings anchored in post-colonial contexts - joined recently by those of Ravi Ahuja on the early colonial period, circulating labor would be virtually ignored in academic writing. ${ }^{10}$

The focus on rural migration to the industrializing cities - modernization-centrism - emphasizes novelty and discontinuity. The increased presence of migrant labor is attributed to unpleasant changes, uprooting, unleashed in the colonial period that forced people out of their hitherto harmonious, stable, economically supportive, agrarian existences located in the sedentary worlds of thousands of peasant villages. This belief and its imputation of subsequent change (for the better or for the worse depending on one's political stance) to the policies of the colonial administration and the interests of metropolitan and indigenous capitalists dies hard. A central question is not whether colonialism and industrial capitalism affected village India - they did - but what pre-existing conditions they affected.

Indeed, a pervasive myth tied to a powerful ideology works to deny the change and mobility of peoples that characterized pre-colonial India. Modernization-centrism and state-centrism reinforce that myth although few scholars intend such a result. Moreover, the contrary finding of recent research notwithstanding, the myth persists. Ravi Ahuja noted that "recent writings on India's colonial period thus often tend to disconnect its precolonial from its colonial past, in order to construct incompatible exogenous and indigenous 'principles' of social organization". " ${ }^{\text {I }}$ The ideal of a harmonious, stable, communitarian Hindu India living in a state of contentment until disrupted by Moslem invasions and British colonialism

I0. Jan Bremen, Of Peasants, Migrants and Paupers: Rural Labour Circulation and Capitalist Production in West India (Delhi, 1985); idem, Footloose Labour: Working in India's Informal Economy (Cambridge, 1996); Ravi Ahuja, "Labour Unsettled: Mobility and Protest in the Madras Region, 1750- I 800", Indian Economic and Social History Review [hereafter IESHR], 35 (1998), pp. 381-404; idem, "Labour Relations in an Early Colonial Context: Madras, c.1750I 800", Modern Asian Studies, 36 (2002), pp. 793-826.

I I. Ahuja, "Labour Relations in an Early Colonial Context", p. 793. 
is a component of Hindutva ideology. David Ludden writes: "Closure and sedentarism are characteristics of civilization in South Asia that have been formed as knowledge by intellectual and political elites in their competitive pursuit of cultural power." ${ }^{2}$

The pre-colonial, colonial, and post-colonial reality was very different from the sedentary myth. Indians (and other South Asians) were and are mobile. Ludden suggests that "half of the population of India in the eighteenth century" would have been made up of a great variety of mobile people ranging from seasonal migrants to "hunters, herders and transporters" living out their lives in "a terrain of perpetual movement". ${ }^{13}$ Even the many inhabitants of the tens of thousands of peasant villages who did (and do) form the majority of the population were not immobilized in their little worlds. Marriage arrangements - and hence kin networks - normally extended beyond the borders of a single village; pilgrimages and periodical fairs (secular, religious and both) drew people out of their villages; itinerant traders and artisans came to villages to sell goods and services; poor peasants and landless laborers found seasonal employment outside their residential village or migrated permanently to nearby or distant places.

Others moved from urban place to urban place. When, for example, the Mughal court moved - as it often did - thousands of hangers-on (servants, artisans, merchants etc.) dependent on imperial patronage, or the support of those the Mughals patronized - moved with them. And what of the extended labor markets for soldiers, and the subsequent mobile life of the soldier, so well described by Dirk Kolff and others? ${ }^{14}$ Circulation, not immobility, needs to be "a fairly general framework within which to look at Indian society and the transformations it underwent in the modern period, that is at least from the eighteenth century, if not from an even earlier period". ${ }^{\text {is }}$

Circulating labor moves to varied temporal rhythms and across different expanses of space. Even when one excludes the many who travel to work daily and return daily to their residences - they are better conceptualized as commuters ("daily migrants" stretches the meanings of migrant and

I 2. David Ludden, "History Outside Civilisation and the Mobility of South Asia", South Asia, ns I7 (1994), pp. I-23, 3. Research by an anthropologist like P.K. Misra also gets "ghetto-ized". See P.K. Misra, "The Study of Nomads", in Surajit Chandra Sinha (ed.), Research Programmes on Cultural Anthropology and Allied Disciplines (Calcutta, I970), pp. I I I-I97.

I 3. David Ludden, "Caste Society and Units of Production in Early-Modern South India", in Burton Stein and Sanjay Subrahmanyam (eds), Institutions and Economic Change in South Asia (Delhi, 1996), pp. 105-133, I09.

I4. Dirk H.A. Kolff, Naukar, Rajput E Sepoy: The Ethnohistory of the Military Labour Market in Hindustan, $1450-1850$ (Cambridge, I990).

I5. Claude Markovits, Jacques Pouchepadass, and Sanjay Subrahmanyam, "Introduction: Circulation and Society under Colonial Rule", in idem (eds), Society and Circulation: Mobile People and Itinerant Cultures in South Asia I750-1950 (Delhi, 2003), pp. I-22, 3. 
migration) - one is left with large numbers whose search for employment requires longer-term circulation. Another important variable is who migrates? A male head of household only? An unmarried male? A female only (as in some labor markets for domestics or sex workers - although sex workers are not necessarily female)? An entire family or even larger units joined by ties of residential propinquity, kinship, friendship, or all three? Moreover, migrations are sometimes staggered: first, the male head of household, then his family, and later other kinfolk. The causative pushpull factors and the legal and regulatory frameworks within which migration takes place are equally complicated.

Some of the differences have been touched upon in the paragraphs above. The differences are many and their different combinations make for a complicated matrix of possibilities. The possibilities include, for example, at the end points of many continuums the (a) permanent departure of a single male from a previously fixed abode in India to a specific, permanent place in a distant part of the globe, to (b) frequent movement from worksite to worksite within an Indian region of a family comprised of father, mother, and children embedded in a larger circulating group of similar workers belonging to the same caste or tribe.

More published research may make it possible to construct a useful taxonomy of the types of South Asian migrant labor and the causes and conditions of its movements. However, exercises in overly detailed classification can lead to formal, sterile analyses, so the good sense to know when such efforts reduce rather than enhance understanding of complex, dynamic situations will be needed. Regardless, we are a considerable distance from any such effort: too much is still unknown about many forms of migrant labor in India during the past 500 years and since I 500 is not particularly consequential in this matter, why not the past I,०00 years. Until we know a good deal more we cannot write with authority about the ways in which migrant labor and laboring has - or has not - changed in India from pre-colonial to post-colonial times.

For now, it suffices to distinguish between those who commute to work, those who migrate to find work, and those who are itinerant and circulate for much of their lives. Even within these simple divisions, however, boundaries are blurred. Itinerants usually travel in family groups (often as part of larger collectivities of families) since, to be truly itinerant, there can be no place called home where other family members remain. However, others among the migrant workers may also travel in family units to a place of employment where they will remain for many months or longer. Thanks to the monsoon-induced rainy season, there is a pronounced seasonality to much outdoor construction work in India.

The remainder of this paper focuses on some of the inadequately studied, often numerous, economically important bodies of workers whose existences as itinerant laborers can be traced from pre-colonial to 
colonial to post-colonial times. Construction workers made up a sizeable fraction of circulating labor (although not all construction workers circulated - many were commuters) but they were by no means the only participants. ${ }^{16}$

\section{CIRCULATING LABOR: THE BANJARAS}

One of the most eye-catching of the circulating groups was the Banjaras. ${ }^{17}$ Their main occupation was to transport bulk commodities - they were the common carrier of pre- and early colonial times although they did engage in other occupations including cattle dealing. Huge herds of Banjara bullocks moved salt, sugar, corn, and rice across the sub-continent. A Banjara qafila (caravan) often contained I0,000 or more bullocks, each bullock laden with 250-350lb of goods. Journeys up to 2,000 miles were undertaken. Most Banjaras had no fixed home. The life of the men, women and children of the qafilas was that of travel from one daily encampment to the next as the bullocks progressed at roughly io miles per day. Most Banjaras, except for the young and the infirm, walked alongside the animals.

Banjaras were present in India from early times. ${ }^{18}$ They flourished in the Sultanate and Mughal period - from the north-west deep into the Deccan - because, in those centuries of widespread military campaigning, they came to transport crucial supplies to armies in the field. Instead of maintaining a costly, standing commissariat the sultans and Mughal emperors hired Banjaras. Once hired - and they were astute bargainers the hundreds of tandas (camps - the macro unit headed by a chief, a naik, into which Banjaras were divided; the naik bargained for the tanda and enforced tribal laws; individual Banjara families owned the bullocks; some tandas were Hindu, others Moslem) were faithful to their contracts and, because of their indispensable services, usually permitted unimpeded passage across India. ${ }^{19}$ However, in the event a qafila was attacked the well-armed Banjaras defended themselves vigorously.

Tightened, more widespread British control over India in the early decades of the nineteenth century marked the beginning of the end of six

I6. Weavers also moved in the search for better economic opportunities. See Douglas E. Haynes and Tirthankar Roy, "Conceiving Mobility: Weavers' Migrations in Pre-Colonial and Colonial India”, IESHR, 36 (January-March I999), pp. 35-67.

17. My account is based on Robert G. Varady, "North Indian Banjaras: Their Evolution as Transporters", South Asia: Journal of South Asian Studies, ns 2 (1979), pp. I- I 8; and Laxman D. Satya, "Colonial Sedentarisation and Subjugation: The Case of the Banjaras of Berar i $850-$ 1900", Journal of Peasant Studies, 24 (1997), pp. 314-336.

I8. Romila Thapar, Early India From the Origins to AD I300 (Berkeley, CA, 2002), p. 459.

19. Banjaras were migrant workers providing transportation services. However, they were not wage-laborers but rather groups of cooperating families with shared cultural traits, most of whom owned their means of production. 
centuries of Banjara success as transporters. Colonial authorities increasingly sought to control and to settle the wide-ranging, armed, independent Banjaras and similarly peripatetic groups. ${ }^{20}$ The colonial authorities, in fact, wanted a sedentary, peasant India. The next I 50 years saw the Banjaras struggle to survive and adapt. Railways, the great technology handmaiden of industrial capitalism and the instrument of a strengthened colonial state, opened in India from I 853 onwards and reached a tentacular 23,627 route miles in 1900, largely ended the Banjaras' role as longdistance, bulk commodity transporters.

Ironically, in western India, Banjaras (regionally Vanjaris) in and around Bombay came to have a major presence among those who worked as railway station porters. ${ }^{21}$ Driven out of their role as transporters and into marginal farming, the men then migrated to Bombay in the search of work (albeit, like many other such groups, retaining links to the land and often leaving their families in the villages).

Some Banjaras turned to criminal activity thus intensifying the tendency of colonial authorities to brand them, collectively, a criminal tribe. Others focussed more on what had always been a subsidiary Banjara enterprise, the cattle trade, by driving their herds to local melas (fairs) where they bought and sold livestock. Some settled down at fixed locations where they engaged in cattle grazing and agricultural pursuits, perhaps mixed with some cattle dealing.

A later development (1950s) in the area of motorized road transport gave some Banjaras new opportunities in the business of cattle dealing. The advent in India of the long platform lorry (previous lorries were too small to be useful to the Banjaras) enabled enterprising Banjaras to transport twenty or so bullocks or twenty-five to thirty calves a couple of hundred miles in one day. Quick, flexible, direct fair to fair transport of cattle had become possible and profitable so, with bullock power still essential to the agrarian economy and melas the main loci of cattle dealing, some Banjaras successfully continue in the cattle business. However, now the men ride the lorries. They complain about the amount of time they spend away from their families and remember nostalgically the days when they accompanied their herds on foot. ${ }^{22}$ If we developed a complex categorization of circulating work, the lorry-riding Banjara would have to be located at a different spot on the matrix from either his cattle-dealing early twentieth-century ancestors or his eighteenth-century ancestors who

20. Satya, "Colonial Sedentarisation", pp. 314-336, stresses this theme. Also see the widerranging, more-nuanced contribution by Radhika Singha, "Settle, Mobilize, Verify: Identification Practices in Colonial India”, Studies in History, ns I6 (2000), pp. I I-I98.

2I. Dennis Weitering, "Carrying the Load Together: Mumbai Railway Coolies and their Quest for Labour, Income and Social Security”, (M.A., University of Nijmegen, 2003), pp. 48-52.

22. Varady, "North Indian Banjaras", p. I I. 
manned the great qafilas. The forms and content of such work change over time

The Banjaras were kept amused during their long journeys by accompanying conjurors, astrologers, jugglers, musicians, and entertainers with dancing bears and trained monkeys. ${ }^{23}$ This reminds us just how diverse the occupations of migrant labor were in India. Some people provided goods and services essential to the economies of which they were a part; others, no less mobile, provided entertainment and other activities that formed an integral part of the rich tapestry of daily life and popular cultures.

Neeladri Bhattacharya provides a fine description of the "vast network of peddling trade" in colonial Punjab extending across the North-West Frontier. ${ }^{24}$ Although dominated by Labanas, Khojas, and Banjaras, this network included others who forged the multiple links along which flowed the goods and services that connected villages, towns, and cities over extended distances. Different communities were associated with particular activities but "the boundaries were permeable, the identities multiple and intertwined". "Tramping entertainers and specialists were an intimate part of village life, supplying villagers with their ritual and cultural needs, with entertainment, news and rumours."2s

Acrobats, blacksmiths, genealogists, goldsmiths, Khaswalas (sellers of brushes and ropes made of grass), musicians, and Qalandars with their trained monkeys, plus many others, were parts of the vibrant, mobile mix. As Servan-Schreiber reminds us:

Across a wide swathe of roads in northern India, wandering castes of Bhojpuri singers earn their living even today [early twenty-first century] by performing and singing a variety of tales and songs. Gorakhpanthi ascetics dressed in the ochre garb, Nat dancers with long hair and wearing skirts like women, Noniya singers formerly attached to saltpetre manufactures, Madari Sufis holding the green banner of Islam to receive their alms, and Teli singers accompanying caravans towards the Nepal Terai, all continue to travel either alone or in small groups, instruments in hand. ${ }^{26}$

\section{CONSTRUCTION: PRE-COLONIAL AND COLONIAL}

However, numerous among the migrant workers from deep into the precolonial period to the twenty-first century were those engaged in

23. Ibid., p. 4 and n. 35 .

24. Neeladri Bhattacharya, "Predicaments of Mobility: Peddlers and Itinerants in NineteenthCentury Northwestern India”, in Markovits, Pouchepadass, and Subrahmanyam, Society and Circulation, pp. 163-214, 168 .

25. Ibid., p. 168 .

26. Catherine Servan-Schreiber, "Tellers of Tales, Sellers of Tales: Bhojpuri Peddlers in Northern India", in Markovits, Pouchepadass, and Subrahmanyam, Society and Circulation, pp. $275-305,275-276$. 
construction work. Quite likely, in fact, they were the most numerous, given the ubiquity of construction work. They migrated within rural India, from rural to urban areas and vice versa, as well as from urban area to urban area. An important feature of construction-type work is that it occurs everywhere and continually, albeit time-limited where any specific project is concerned. Lifetime work at a specific construction site rarely occurs although a worker, occasionally, might find a lifetime of work within commuting distance of his or her residence.

This large body of workers was not a homogenous group - no more so than the multiple kinds of things they built (compare, at the extremes, the construction of a small reservoir with the building of the Taj Mahal; or a road in rural Punjab with the city of Chandigarh). Many occupations and many castes or tribes (or possessors of other cultural signifiers) engaged in construction work and they migrated to worksites over different distances, according to different temporal rhythms, individually or in differently sized and differently composed social units. Indeed, many who worked in construction did so as commuters.

In Mughal times, as in later times, the workers and artisans collected at a construction site (construction of Akbar's Fort at Agra required 3,000 to 4,000 artisans, laborers, and functionaries daily) were "both local and those brought from different regions of the country". ${ }^{27}$ Highly skilled artisans were part of the construction workforce as were women and children who carried earth in little baskets on their heads from borrow pit to tip. Mughal paintings "help us to identify skilled and non-skilled labour: the latter, often scantily clothed, run about doing sundry jobs". ${ }^{28}$ Women laborers appear in Mughal paintings but not children, although we know children were present at construction sites in the nineteenth century.

An important grouping among those engaged in construction was the workers in earth and stone like those described in Madras in 1770 . Similar groups existed throughout India but they were not identical, despite sharing a similar niche in the labor market and a mobile life style. The different socio-cultural groups of earth-workers tended to be broadly regional in their ambulatory patterns: for example Odhs in the Punjab, Nuniyas in the central Gangetic valley, Oddar in southern and western India. The latter, with names specific to the regional languages of the south and west (e.g. Vaddar in Kannada) were known generically to the British as Wudders. Likely originating in Telegu speaking parts of the Deccan south, they were most probably the workers seen by Paterson in 1770.

We know, too, that some communities in the grouping (quite likely most) had a history that extended deep into India's past. One finds 
speculation in the Eliot manuscripts that Vaddars - referred to as a "numerous and widely spread Caste" may have been Buddhists in the eleventh century. ${ }^{29}$ And, dating from the same century, we have a specific story about a foundation victim (the need to have a human sacrifice to ensure the permanence of a building or the embankment of a reservoir) that states that Raja Jayasinha Siddharaja, (who ruled the Caulukya kingdom located in Gujerat/southern Rajasthan, also know as the Solankis of Anahilapataka, i.e. Patan, from I094-I I43) abducted "a woman of the Od or navvy caste, but she cursed him that his lake at Patan should never hold water, and it never did until Mayo, a Dheda scavenger, was sacrificed"..$^{\circ}$ Tradition places the arrival of itinerant earth-working communities in south India, in and around Madurai, to the Nayaka kingdoms established in the late sixteenth century after the break-up of the great Vijayanagara dynasty. ${ }^{3 \mathrm{I}}$

Paterson, we know, testified to the considerable presence of nomadic earth-workers in Madras in the I770s. He labeled them a "particular cast [sic] of people called Tank diggers" thus indicating one of their main activities in south India where, especially in the dryer Deccan interior, water storage was a major concern. He mentions groups as large as 2000 men, women and children whose

[...] sole business is to dig Tanks, Ditches, Wells, carry Earth, work in Gardens, on Fortifications etc. Their only instruments are a Mamotty (a broad kind of hoe with a short handle) and a basket. And as they excell in this kind of work, one doing more than three or four Coolies, they are much sought after and even courted by Princes to remain in their Country. ${ }^{32}$

When John Sullivan wrote to the East India Company Court of Directors on 3 February 1779 about a canal to permit water to flow from the Krishna and Godaveri Rivers into the Cauvery River he argued it would not - as some feared - draw laboring people too much from cultivation because of a "peculiar institution" among the Hindus whereby a group "of great numbers" and "peculiar robustness" separate "from all other orders of the Society" dug canals. ${ }^{33}$ Sullivan said these people were known by the "name expressive of their occupation (Tank Diggers) [...]" and that they had no fixed residence but wandered about with their

29. OIOC, MS Eur. D317, Eliot Manuscript, pp. 21 I-213.

30. William Crooke, Religion E Folklore of Northern India, prepared for the press by R.E. Enthoven (new edn, New Delhi, I926), p. I Iо.

31. J.H. Nelson, The Madura Country: A Manual Compiled by Order of the Madras Government (Madras, I868), Pt 2: "Ethnology, Fauna and Flora", p. 88.

32. OIOC, Paterson Diaries, 23 November 1770 , p. 98.

33. OIOC, Mackenzie Collection: General, vol. 59: Water Works in the Carnatic, "Appendix to the Memoir on Watering the Circars", by Alexander Dalrymple (London, 1793) in which a long extract from Sullivan's letter is found plus Dalrymple's comments. 
families in search of work. Alexander Dalrymple reproduced and commented on Sullivan's letter in I793. Dalrymple recounted his experience on the works of Fort St George (at Madras) in 1756 where "multitudes" were employed to argue Sullivan was "mistaken in supposing all other are by caste excluded from the labour of removing earth".

It was an important correction. The nomadically inclined groups like the Wudders were never the only earth-workers; indeed, they were rarely the majority at the many big construction projects undertaken from the i $840 \mathrm{~S}$ onwards. Dalrymple stated that an argument for the proposed canal was the vast numbers it would employ - numbers, he implied, that would include general laborers from the immediate locality in addition to the nomadic groups. One suspects that throughout the eighteenth, nineteenth, and part of the twentieth centuries the circulating groups acted as pacesetters whose effectiveness as earth-movers set the standards by which employers established payment rates for earth-work. To reemphasize an important point: construction work usually employed many whose sole or main occupation was not construction. Construction work was a fluid category ill-suited to the subsequent enumerative practices of colonial or post-colonial census takers who consistently understated the numbers involved.

Subsequent descriptions of earth-working groups are similar to those provided in the late eighteenth century. Substantial numbers, nomadism, a preference for contracted piece-work negotiated by a headman on behalf of the group, community cohesion and the internal enforcement of community norms and values including, according to Paterson, decapitation by the mamotty for serious crimes, collective work by men, women, and children using the simplest of tools, and the fact that these groups moved earth much more effectively than ordinary laborers find repeated description.

In the first decade of the nineteenth century, the keen observer Francis Buchanan encountered similar groups during his travels across Mysore, Kanara, and Malabar. He called them "Woddas, or Woddaru [...] a tribe of Telinga origin" who retained the Telegu language despite their presence throughout Tamil- and Kannada-speaking areas. ${ }^{34}$ Buchanan's description deserves extended reproduction because it raises issues important to the discussion pursued in this paper. It is, moreover, the most fulsome of the early ethnographies and, since it was read by later observers, an influence on their perceptions of the Wudders and similar groups. ${ }^{35}$

34. Francis Buchanan, A Journey From Madras Through the Countries of Mysore, Canara, and Malabar, 3 vols (London, I 807), vol. I, p. 3 10. Most writers hold that the Wudders originated in Telegu-speaking areas although some suggest they moved to what is now Andhra from places in what is now Orissa.

35. Ibid., pp. 310-3 I I. 
They dig canals, wells and tanks; build dams and reservoirs; make roads; and trade in salt, and grain. Some of them are farmers, but they never hire themselves out as Batiguru, or servants employed in agriculture. Some of them build mudhouses; but this is not a proper occupation for persons of their cast [sic]. The old and infirm live in huts near villages; and dig and repair tanks, or wells, or perform other such labour; while the vigorous youth of both sexes travel about in caravans with oxen and asses, in pursuit of trade. In these caravans they carry with them all their infants, and their huts, which latter consist of a few sticks and mats. They follow armies to supply them with grain, and in time of peace take to the lower Carnatic grain, Jagory, and tamarinds, and bring up salt. In Hyder's government they were very numerous; but, having been forced by Tippoo to work at his forts without adequate pay, a great number of them retired to other countries. As they are a very useful set of people, they are now encouraged, and are fast returning. There are no distinctions among them that prevent intermarriages, or eating in common.

Buchanan continues with a description of the customary practices of the Wudders, including simple marriage ceremonies, the presence of a modest bride-price, eating all meat except carrion, drinking spirituous liquors, burial rather than cremation of the dead, a claim to being pure Sudras, and a Vaishnava faith - a description similar in general outline, if not always in specific detail, to many subsequent accounts of the Wudders.

The subsequent accounts did not represent the construction of an "ideal" discourse about an unchanging, stereotypical earth-working group divorced from actual observation. Later writers (many of whom had read Buchanan) in the gazetteers, the census reports, and the distillation of much from those into the multi-volume, early twentieth-century handbooks of castes and tribes often engaged in their own direct observation and enumeration (the writers often had field experience as administrators or other colonial postings). Nonetheless, some distillation and essentializing took place. Used suggestively and not proscriptively, the essentialized fierceness of lions, cleverly used by Edward Said to illustrate the construction of powerful discourses, can be used to understand how, with each iteration, the distinctive characteristics of the Wudders as nomadic "others" got reinforced..$^{36}$

The foundational account by Buchanan, however, is striking for its portrayal of occupational and generational fluidity among the Wudders. The old and infirm were not itinerant; the Wudders were earth-workers and traders - indeed, in parts of Buchanan's description, they seem more like Banjaras; and the Wudders as a whole showed little internal differentiation and no barriers to intermarriage. Bhattacharya's assessment quoted above deserves repeating: different communities were associated 
with particular activities but "the boundaries were permeable, the identities multiple and intertwined". ${ }^{37}$

\section{STIGMATIZATION}

Later accounts became more judgmental and more inclined to place Wudders - and similar groups - into less permeable but more internally differentiated categories. Nelson, writing in I 868, refers to them as strong and hard-working but also "drunken, gluttonous and vicious". ${ }^{8}$ He said Wudders could not be trusted, since they sometimes took advances from half a dozen employers in one week and worked for none of them if they could. The I885 Poona District Gazetteer refers to itinerant Vadars (significantly classified under the sub-heading "unsettled tribes"), likely of Telegu extraction, who entered the area in the i 850 s and who were divided into three divisions: Gadi-vadars or cartmen, Jate-vadars or grindstone men, and Mati-vadars or quarrymen. Members of the three divisions could eat together but did not intermarry. 39 By the time Edgar Thurston published (I 909) his monumental compendium Castes and Tribes of Southern India, the Odde, the Tamil name Thurston uses for his Wudder entry - with other regional names used within the entry - the Kallu Vaddas (stone-workers and builders) considered themselves superior to Mannu Vaddas (earth-workers) with whom they would neither intermarry nor eat - at least in Mysore. $4^{\circ}$ The colonial gaze with its instrumental need for classification and enumeration went on to divide the Vaddas into twenty-three exogamous septs. $4^{\mathrm{I}}$

Thurston's material also includes the presence among the Wudders of groups that had taken to "crime as a profession" and who had become "skillful burglars and inveterate robbers". ${ }^{22}$ Stone Wudders were chiefly represented because, as builders and stone-cutters, they went about "under the pretence of mending grindstones" during which they "obtain much

37. Bhattacharya, "Predicaments of Mobility", p. I68. Satya, "Colonial Sedentarisation", pp. 314-336 makes similar observations about the pre- and early colonial Banjaras.

38. Nelson, The Madura Country, p. 88.

39. Gazetteer of the Bombay Presidency, I7, Pt I: Poona (Bombay, I885), pp. 426-428. They were called "excellent workers, almost always working by the piece", but also "poor" and not inclined to take to "new pursuits".

40. Edgar Thurston, assisted by K. Rangachari, Castes and Tribes of Southern India, 6 vols (Madras, 1909), vol. 5, pp. 422-436. The Wudders have been studied by Chandrashekhar Bhat, Ethnicity and Mobility: Emerging Ethnic Identity and Social Mobility among the Waddars of South India (New Delhi, I984). His book draws upon some of the sources I use. It also provides a case study of a Waddar settlement in Karnataka (started in the mid I940s) and the processes of Wudder sedentarization and upward social mobility.

4I. Bernard S. Cohn, Colonialism and its Forms of Knowledge: The British in India (Delhi, 1997) explores the processes of classification and enumeration.

42. Thurston, Castes and Tribes, p. 434. 
useful information as to the houses to be looted or parties of travellers to be attacked". ${ }^{43}$ By the early twentieth century Wudders also had begun to appear in manuals describing what the authorities labeled - as a legal category subject to special rules - criminal castes and tribes. ${ }^{44}$ The socially distinctive tribes of India had, since early times, an ambivalent relationship with Hindu caste-societies (which, to repeat, were not homogenous, monolithic, and static). They were distinct but they were also in continual interaction with settled caste societies: indeed, as itinerant groups, they moved in the interstices between those settled groups to whom they provided crucial goods and services. "As the 'Other' they also defined the 'Self' and were categorically considered culturally inferior, though not always oppressed." 45

T.N. Atre captured well the important yet marginalized and stigmatized roles nomadic groups played in the lives of Maharastrian villagers in the late nineteenth and early twentieth century. His Gaav Gada, published in I9I 2 in Marathi and translated into English (2000), includes a chapter on "The Nomads". ${ }^{6}$ Atre identified regular visitors to a village, usually at harvest time, whom he labels vatandars. They usually had a fixed schedule and maintained "themselves either by selling their wares, doing odd jobs, or by begging". Vatandars were contrasted to "wanderers who do not necessarily stick to any traditional schedule" whom he labels "uplani or outsiders". He then goes on to describe in considerable detail the many groups that fit within his two categories. He states that many know "some art or form of entertainment" but "if one pulls the veil aside a little, one would be convinced that their main object is begging and thereafter cheating, deceit, theft and in some cases clandestine sexual relations".

Earth-working Wudders (uplani) traveling in groups of five to fifteen families were among those Atre described. They settled on the village outskirts in grass-covered tents along with their donkeys, sheep, and goats. They took contracts from the engineers but the women and children also begged in the villages. They also sold the same stone articles as the beldars - an example of the permeable categories mentioned earlier. Atre calls some sub-castes of Wudders criminals and describes their illegal activities and methods of operation. Indeed, much of his chapter on "The Nomads" is devoted to stigmatization, to the discussion of the criminal behavior of

43. Ibid.

44. The Criminal Tribes of India Series, No. I: Rai Bahadur M. Pauparao Naidu, The History of Railway Thieves With Illustrations E Hints on Detection (4th edn, Madras, I9I 5), pp. I I9-I44. 45. Aloka Parasher-Sen, "Introduction", in idem (ed.), Subordinate and Marginal Groups in Early India (New Delhi, 2004), p. 5. Parasher-Sen includes tribes and foreigners among the "outsiders"; Satya, "Colonial Sedentarisation", provides a more harmonious picture of villager/ nomad relationships, at least where Berar and the Banjaras was concerned.

46. T.N. Atre, The Village Cart; a translation of T.N. Atre's Gaav Gada by Ram Deshmukh (Mumbai, 2000). Nomads are covered in ch. 6, pp. I 8 - I38. All quotations are from this chapter. 
the migrant groups. He concludes by advocating the active use of colonial laws and police powers to control the nomads. Atre, it should be noted, served in the colonial administration as a low-level revenue officer and then as a sub-judge.

The colonial authorities did seek to marginalize, compartmentalize, and criminalize itinerant groups like the Banjaras and the Wudders. Surveillance of their activities was increased and regulatory and legal mechanisms instituted to control them. If many itinerant groups had an ambivalent but accepted role in pre-colonial India, the state-centrism and anxieties (after all, the alien few ruled the indigenous many) of the colonial authorities fostered a less accommodative view. Itinerant groups came to be seen as threats, actual or potential, to social stability and regime security. Traditional patterns of circulation came to be seen as a "radical contestation of colonial rule".47 Sedentary subjects were more easily controlled: the myth of sedentary, immobile India was partially created out of the emergent realities and ideologies of the high colonial period. The itinerant "Others" were marginalized, stereotyped, and then stigmatized in ways that paralleled the repressive treatment of vagrant groups in Europe detailed by Leo Lucassen. $4^{8}$ Those considered particularly threatening were collectively designated criminal tribes and castes and brought under the draconian provisions of the Criminal Tribes Act (Act XVII of I 87 I $) .49$

The authorities placed some Wudder sub-groups on the list of criminal tribes. Some of these, in turn, entered the ethnographic literature as Donga Wuddiwars "or [literally] thieving Wudders, from their fact of their having taken to crime as a profession"..$^{\circ}$ Police at the Kolar Gold Field reported in I913-1914, and again in I915-I916, that close watch had been kept on the movements of criminal gangs with "thieving proclivities" such as the Wudders and the Korachars. ${ }^{\text {I }}$ Later classificatory schemes such as those of scheduled castes and tribes initiated in 1935 found the Wuddurs in Mysore State listed among the scheduled castes, while in other jurisdictions they were considered criminal tribes. The classificatory confusion continued in post-colonial India where, in some areas, Wuddurs were

47. Arnaud Sauli, "Circulation and Authority: Police, Public Space and Territorial Control in Punjab, I86I-1920", in Markovits, Pouchepadass, and Subrahmanyam, Society and Circulation, pp. $215-239,216$.

48. Lucassen, "Eternal Vagrants", esp. pp. $225-227,240-248$.

49. See, as one example from a growing literature, Sanjay Nigam, "Disciplining and Policing the 'Criminals by Birth", Pt r: "The Making of a Colonial Stereotype - The Criminal Tribes and Castes of North India”; Pt 2: “The Development of a Disciplinary System, I87 I-I900”, IESHR, 27 (1990), pp. I3I-I64, 257-287.

50. Thurston, Castes and Tribes, p. 434.

5I. Mysore Geological Department, Report of the Chief Inspector of Mines for the Year I9I5I6 with statistics for the calendar year I9I5 (Bangalore, I918), p. 24. 
designated a criminal and wandering tribe, in other areas a backward and depressed class, and in yet other areas an untouchable and depressed caste. $^{52}$ A section of the earth-working Oudhia (Odh) caste in North India also found themselves listed among the so-called criminal tribes. ${ }^{53}$ Neither the fondness for classification nor the notion of collective criminality disappeared in 1947 .

However, to return to Thurston and to the issues of migrant labor and occupational niches: his sources attest to the variety of occupations in which early twentieth-century Wudders were involved. Those included felling trees in the forested hills of the Kurnool district from which their bullocks dragged the timber. Significantly, some Wudders were reported to have settled permanently on the outskirts of large towns where men and women found jobs as sweepers in sanitation and conservancy activities. Others had found work in the Mysore manganese mines. Nonetheless, varieties of construction work continued to be most favored. Finally, Thurston quotes with approval a comment about British navvies. They were, he wrote, largely unknowns who risked their lives to construct the facilities upon which "modern civilized life largely depend" and whose "claim on our sympathies is universal". These remarks, he states, "apply with equal force to the Oddes, who numbered 498,388 in the Madras Presidency at the census, I90I". ${ }^{54} \mathrm{He}$ did not add that in the case of the Wudders, "civilized life" was equally indebted to the labor of women and children.

\section{THE HIGH COLONIAL PERIOD}

The high colonial period witnessed an explosive increase in the demand for construction labor of all kinds. Across India, the I89I Census enumerated IIO,I42 involved in the production of building materials but considered that number to be an understatement because, among other reasons, many engaged in brick-burning returned themselves as potters, their traditional caste occupation. I,027,597 were returned as "artificers in building". Those involved in "earth-work \&c" numbered $\mathrm{I}, 647,7 \mathrm{IO}$. These numbers total 2,785,449: a considerable number but too small, since some among the $23,820,277$ returned as "general labour" (primarily unskilled agricultural laborers according to the Census), found their way into construction work - if only temporarily on projects near to their places of residence. 55

Earth-workers were required in huge numbers for large-scale canal and

52. Bhat, Ethnicity and Mobility, pp. 36-38.

53. Stephen Fuchs, At the Bottom of Indian Society: The Harijan and Other Low Castes (New Delhi, I981), p. 57.

54. Thurston, Castes and Tribes, pp. $435-436$.

55. General Report on the Census of India, I89I (London, I893), esp. pp. 103-I I 2. 
reservoir building - the massive Ganges canal was begun in the I840s and the subsequent century witnessed a series of large hydraulic projects in many parts of India ranging from the canals and canal colonies of the Punjab to the Krishnarajasagar dam in Mysore. Similarly, the lengthy construction of New Delhi (c.1912-c.1935) as the capital of the British Indian Empire required large numbers of earth-workers and more skilled construction workers (notably masons but also electricians, plumbers, and other skilled trades).

22,000 laborers were employed on the new capital in April of I9I 4 and I9I5, and 30,000 in 1929. ${ }^{56}$ Some 13,300 artisans and workmen were enumerated in New Delhi and 60,000 in old Delhi at the I93 I Census. ${ }^{57}$ How many counted in old Delhi were employed in New Delhi is unknown, but some clearly were. ${ }^{58} 9,000$ men, women and children (all but the younger children worked) were housed in the coolie camp at Safdar Jang and the rest were in camps scattered throughout the area.59 The mud, thatched-roof huts in the camps were described as "unfit for human habitation". ${ }^{60}$ Pay and working conditions could be deplorable. One member of the RLC found an emaciated, naked I I-year-old boy working for 2 annas a day. ${ }^{61}$

The substantial but fluctuating supply and demand for construction workers for New Delhi was met primarily by people who migrated from Bikanir and Rajasthan. Skilled workers, however, came from across North India. ${ }^{62}$ Initially, much of the migration of the unskilled workers was seasonal with many returning to their villages as the agricultural cycle dictated. However, increasing numbers made Delhi their permanent home and seasonal or other forms of circulation gave way to residence in or near Delhi. This, however, created a problem in the late i 920 and early I930s when the major public works required for the new capital were completed and the demand for construction workers slackened. Unemployment grew and wages, never generous, were lowered. ${ }^{63}$

Figures $\mathrm{Ia}$ and $\mathrm{Ib}$ opposite provide a fascinating glimpse of the latter stages of the construction of monumental New Delhi. The photographs show the laying of the topmost stone on the crown finial of the North Block of the Secretariat on 30 September 1927. Masons, overseers, an

56. Royal Commission on Labour in India. Evidence, 2, Pt 2: Punjab, Delhi and AjmerMerwara: Oral Evidence [hereafter RLC, Oral Evidence] (London, I93 I), pp. I38, I95.

57. Census of India, I93 I: Delhi, Report and Tables (Lahore, 1933), p. 43.

58. Royal Commission on Labour in India Evidence, 2, Pt I: Punjab, Delhi and AjmerMerwara. Written Evidence [hereafter RLC, Written Evidence], (London, 1931), p. I 54.

59. Census of India, 1931: Delhi, Report and Tables, p. 43.

60. RLC, Written Evidence, p. I55.

6I. RLC, Oral Evidence, p. 2 II.

62. RLC, Written Evidence, p. I54.

63. Ibid. 


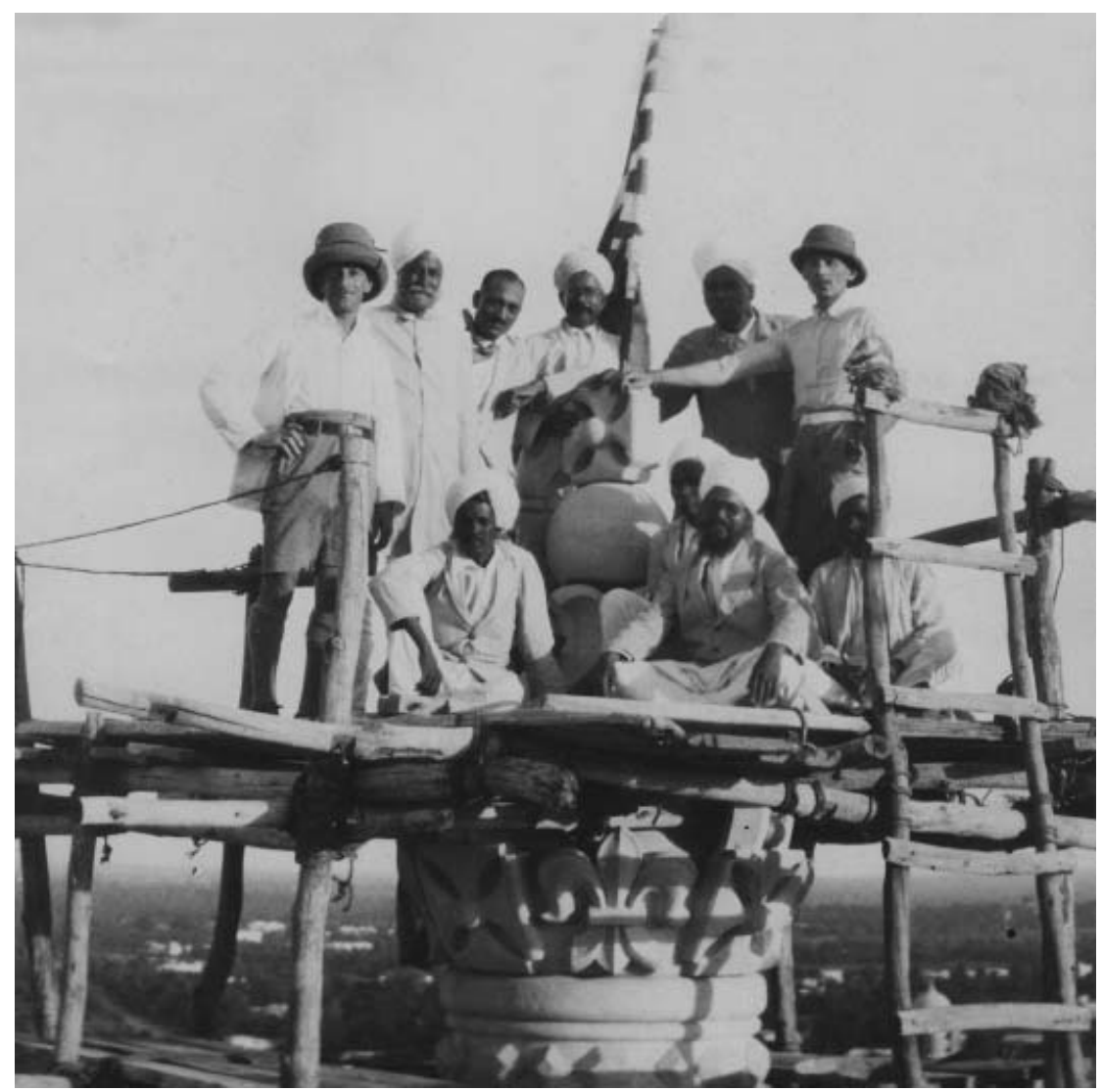

(a)

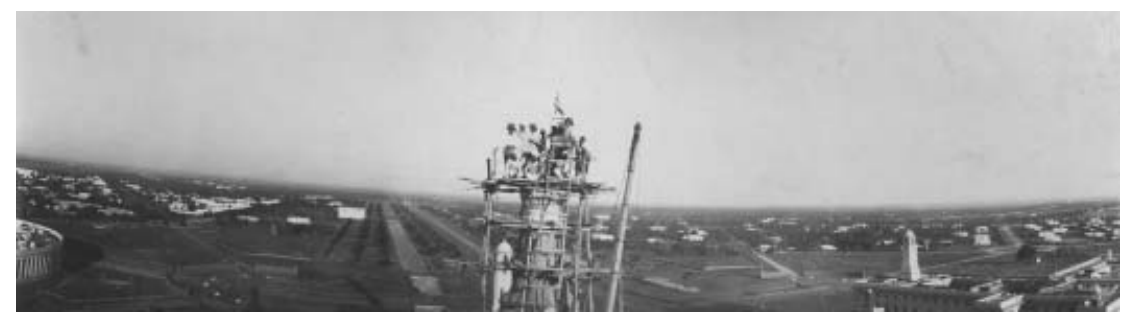

(b)

Figure ra and $\mathrm{rb}$. Laying the topmost stone (one of two) of New Delhi, the crown finial on the North Block of the Secretariat, 30 September 1927. The close-up in the upper panel includes, standing left to right, H.W. Pippet, (junior) foreman mason; Rai Bahadur Sardar Baisakha Singh, contractor; Khan Bahadur Muhammad Sulaiman, executive engineer, CPWD; Lala Shadi Ram and Lala Chela Ram, sub-divisional officers, CPWD, and H.A.N. Medd, resident architect. The sitting participants are overseers and masons.

The two photographs from which this composite image was created are found in the photographic collection of the Centre of South Asian Studies, University of Cambridge, Box A9I, Medd, H.A.N., Album \#4: "New Delhi: Building the Government Offices", pp. I2 and I3. The images are reproduced with the kind permission of the Centre of South Asian Studies. 
executive engineer, a major contractor Baisakha Singh, and the resident architect are posed triumphantly far above the ground in a silent, telling tribute to the labor of tens of thousands of men, women and children that built imperial New Delhi.

The example of New Delhi illustrates a number of the features of circulating construction labor suggested in this paper: (I) the concentration of large numbers of workers drawn from widespread areas at the sites of major construction projects; (2) the presence of many people whose main occupation remained agriculture (albeit often as landless laborers), and who circulated back into agricultural employment at certain times in the year; (3) the difficult conditions under which the construction people worked and lived. An additional pattern present among the New Delhi construction workers - the decision of a substantial number to make the Delhi region their permanent home - was a variation present in situations where, as in large urban projects, employment prospects and other inducements made permanent residence seem appealing. The construction at Jamshedpur earlier in the twentieth century and at Chandigarh in the mid-twentieth century may have offered similar scenarios. Dam and evermoving railway construction rarely led to the permanent sedentarization of hitherto circulating labor.

A full appreciation of the emergent - and then increasingly integrated construction labor markets - will require an extended study of contractors. They were the crucial intermediaries. They are one of the most neglected groups in the history of Indian labor - or, for that matter, in the history of the growth and development of the Indian bourgeoisie. ${ }^{64}$ Contractors came in all shapes and sizes. Some were little more than mukaddams (roughly headmen) who could assemble and command a small gang of laborers. Some like Baisakha Singh, a trained engineer who gave evidence to the Royal Commission on Labour and who won construction contracts at New Delhi in the I920s, employed over 2,000 workers at farflung locations ( 500 at New Delhi). He provided labor, materials, and project supervision. ${ }^{65}$ Larger contractors used smaller labor contractors layers of intermediaries existed - and advances often glued those who provided labor power to those who employed labor.

Ten million or so workers were needed to build India's railways between I 850 and I 900 and large numbers continued to be needed into the I970s. Railway construction at any given spot often required migrant laborers, among whom many were Wudders and similar groups. ${ }^{66}$ The Wudders were prized by railway engineers and contractors for their

64. See Burton Stein, "Towards an Indian Petty Bourgeoisie: Outline of an Approach", Economic and Political Weekly, 26 (26 January 199I), pp. PE9--PE20.

65. RLC, Oral Evidence, pp. I34-135.

66. Ian J. Kerr, Building the Railways of the Raj 1850-1900 (Delhi, I995), pp. 196-226. 


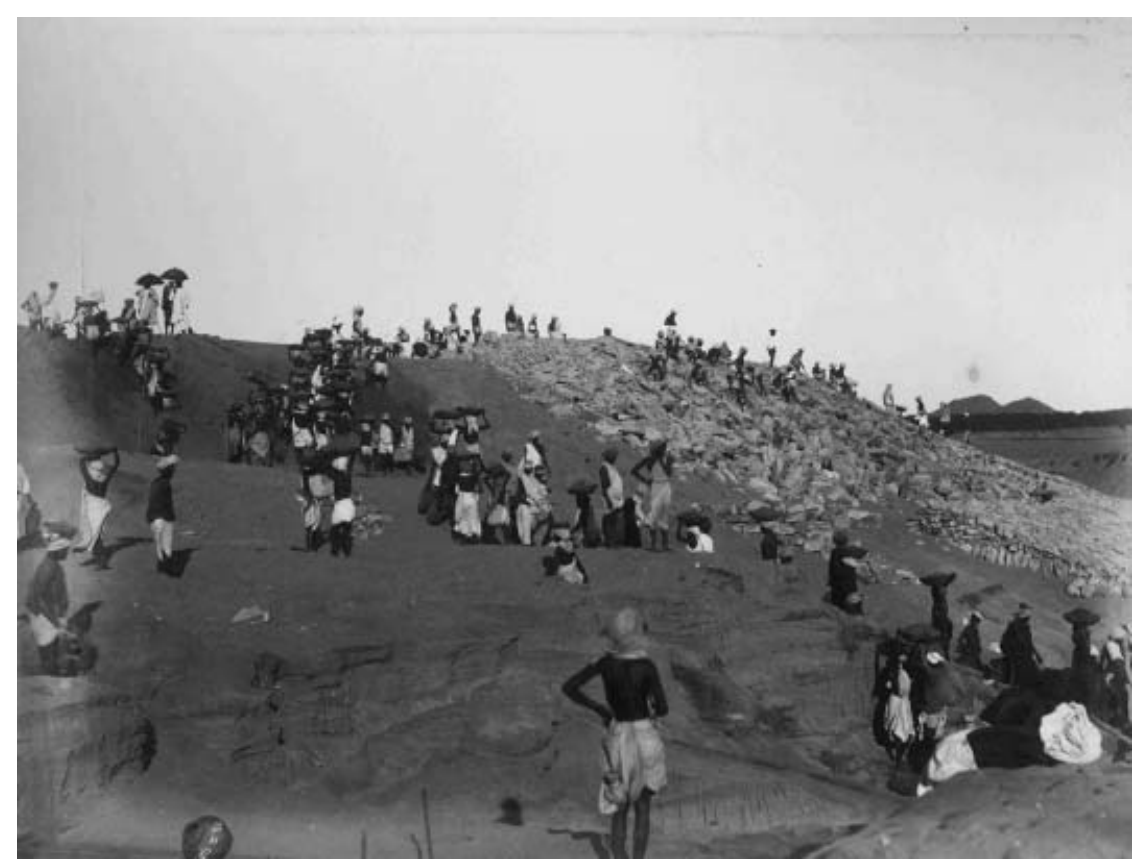

Figure 2. Kistna Bridge, Construction of the Western River-Training Embankment, c.I 892. From an album "Kistna Bridge, Bezwada I2 spans of 30 Feet", F.J.E. Spring, L.C.E, M.I.C.E., engineer-in-chief. Held in the Library of the Institution of Civil Engineers, London and reproduced with the kind permission of the Institution.

formidable earth- and stone-working capacities. Wudders were among those present at the construction of the East Coast State Railway's Kistna Bridge at Bezwada in the early $18905 .{ }^{67}$ Part of that massive project is shown in Figure 2 above. The photograph captures well the large numbers of workers that would crowd upon a major construction site.

I have detailed elsewhere the processes by which labor for railway construction up to I 900 was mobilized and utilized. ${ }^{68}$ Here I wish to emphasize that railway building as a labor-intensive activity continued until I 947 and well beyond. If India had 23,627 route miles of railways in I900, it had 40,524 in I 947 and, after the division of lines between India and Pakistan, India alone climbed back to roughly 40,000 route miles in $200 \mathrm{I}$, indicating the construction of roughly 6,500 new miles of track. Moreover, the closing decades of the twentieth century saw Indian Railways convert many miles of meter-gauge line to the more prevalent 
broad gauge ( 5 feet 6 inches) - this required a good deal of constructiontype labor. These projects frequently used itinerant labor.

Railways, hydraulic projects, highways, and other great construction activities (e.g., the Bhakra Nangal hydro and irrigation dam, underground railways in Calcutta and Delhi) ensured the continued demand for construction workers in post-colonial India. Indeed, India's great urban areas have been and continue to be the sites of massive construction efforts. The Delhi capital region is a major case in point. The construction of monumental New Delhi discussed above has been followed by massive waves of expansion and construction since 1947: a development spurred by the 1947-1948 influxes of refugees and the subsequent massive population growth of India's capital region. The numbers are likely underestimates but one study indicates that in nine of the years between I955 and I970 the building industry in Delhi each year employed over 50,000 workers with the lowest year (1963) being 23,500 and the highest (1967) 71,200.69

\section{THE POST-COLONIAL PERIOD AND SOME CONCLUDING OBSERVATIONS}

Thus, most construction work in the pre-colonial, colonial or postcolonial periods must be examined as a related activity whose requirements for labor power were met from within (increasingly better integrated) labor markets involving circulating labor. A study conducted in the I 970 s noted that migrant labor had integrated the construction labor market. ${ }^{70}$ Migrant labor stabilized (depressed might be a better word) wage rates and flattened labor supply curves. Contractors on big projects imported migrant labor when the cost of local labor rose. The migrants, more desperate for work, were cheaper although they had to be imported. "Thanks to the availability and mobility of migrant laborers, construction employers can, given sufficient time, avoid a general labor shortage or a highly inelastic labor supply, even if local labor supply becomes increasingly inelastic." 7 I

However, change has occurred recently in some instances of large-scale construction. A railroad engineer writing in the late I990s stated that twenty to thirty years earlier: ${ }^{72}$

69. C.K. Johri and S.M. Pandey, Employment Relationship in the Building Industry: A Study in Delhi (New Delhi, I972), p. 2.

70. International Bank for Reconstruction and Development [World Bank], Bank Staff Working Paper no. 223, "Some Aspects of Unskilled Labor Markets for Civil Construction in India: Observations Based on Field Investigation", prepared by Swadesh R. Bose, November 1975, pp. 34-35.

71. Ibid., p. 35 .

72. A Treatise on Konkan Railway (Navi Mumbai, c.1999), p. I47. 
Contractors and agents used to bring gangs from Orissa, after paying an advance to the workers' families and the village headmen. Able-bodied people from entire villages were brought in, to work almost sixteen hours daily, breaking up only for meals, which used to be cooked centrally. They were by far the most efficient gangs. They were gangs from other places as well, during the working season. Camels and donkeys used to be used for leading and massive works would be completed in this way.

This description could easily have been that of nineteenth-century construction. The work of the Odhs in later nineteenth-century Punjab was described thus: "the men dig, the women carry the earth to the donkeys, which they always have with them, and the children drive the donkeys to the spoil bank". ${ }^{73}$ However, the railroad engineer was comparing construction in the I960s and I970s with what occurred when the $760-\mathrm{km}$ West Coast Konkan line between Roha and Mangalore was built in the I990s. He went on to say that "now, with modern methods available and the fact few people are willing to do such a hard job, work is done through mechanical means". ${ }^{74}$ Insofar as large-scale projects like the Konkan line were concerned - projects where capital-intensive practices made economic sense - the i25-year use of great agglomerations of laborers, many of them migrants, had ended.

The pivotal groups of construction workers discussed in this paper were those who practiced an itinerant life-style and who moved in family groups to a succession of construction sites. We know them best by a series of regional caste/tribe names multiplied into variant forms by the vagaries of British transliterations of Indian names into English. Among the most important groups were the Odhs of the Punjab, Rajasthan, and Western Uttar Pradesh, the Nuniyas of the Gangetic valley, the Beldars of Bihar and western Bengal, and, best documented, the groups the British called "Wudders" who were found in western, central, and southern India." These groups, or people like them, were present early in the history of India and continuously thereafter. They flourished in the high colonial period when an explosive increase in the demand for construction labor occasioned by massive railway and hydraulic projects made their earth and stone-working abilities highly valued. They were rarely the only migrant workers at construction sites but they were the pace-setters. Engineers consistently referred to them as the "professional navvies" of India who worked more rapidly than any other group.

73. W. Crooke, The Tribes and Castes of the North-Western Provinces and Oudh, 4 vols (Calcutta, I896), vol. 4, p. 95 .

74. A Treatise on Konkan Railway, p. I48.

75. There was persistent speculation in the folklore/ethnological periodicals that these groups shared a common origin. For examples see Panjab Notes and Queries, A Monthly Periodical Devoted to the Systematic Collection of Authentic Notes and Scraps of Information regarding the Country and the People, R.C. Temple (ed.), 2 vols (1884). 
Mobile and accustomed to waged work (albeit filtered through the collectivity via piece-work payments) the itinerant construction workers initially adapted easily to the changing conditions of the colonial period. They became enmeshed in the relationships of capitalism - certainly railway construction was a project of colonialism and capitalism (intertwined but not identical processes and structures) - via processes Marx labeled the formal subsumption of labor under capitalism. ${ }^{76}$ However, and despite the appreciation many engineers and contractors had for their capacity to work hard, they also came under the suspicious eye of colonial authorities. Some among them became the objects of police surveillance and legal restrictions. The rich and fascinating ethnographic descriptions became a basis for the disapproval of itinerant lifestyles and the attributions of collective criminality.

Ecological, social, legal and economic pressures in the twentieth century increasingly led to the sedentarization of itinerant construction workers and other itinerant groups like the Banjaras. Employment as migrant construction workers was not necessarily abandoned but the distinctive, centuries-old lifestyles of the Wudders and others had to give way to more settled lives. Moreover, in an ever more populated India nomadic peoples ran out of space. As P.K. Misra observed in I970, social, economic, and political changes had led nomadic peoples everywhere to settle down - a process "marked in India too and this process has been further accentuated on account of the rapid planned development". ${ }^{77}$ If Odhs in the midnineteenth century building canals in the Upper Doab were reluctant to take work further south because the more developed state of agriculture in the Lower Doab provided limited space in which they could graze their large herds of cattle and donkeys, then their successors in the midtwentieth century found themselves more hemmed in. ${ }^{78}$ The economic development the itinerant navvies of India helped to bring about - the infrastructures of modern civilized life praised by Thurston - contributed to their sedentarization.

In addition to the importance of circulating labor within construction labor markets these groups offer a jagged terrain that throws into sharp relief the history of South Asian labor within the transitions of capitalism and the emergence, maintenance and demise of formal colonialism. It is a history within which the nomadic proclivities of the itinerant groups have been steadily circumscribed. In the early twenty-first century, fewer itinerant workers exist than they did a century ago although the general category of migrant workers has shown no such diminution. The more

76. My use of Marx 's concept is discussed in Kerr, Building the Railways of the Raj, pp. 7-9. 77. Misra, "Study of Nomads", p. I 5 I.

78. Ian Stone, Canal Irrigation in British India: Perspectives on Technological Change in a Peasant Economy (Cambridge, 1984), p. 58. 
pronounced fluidity captured in the term circulating labor has given way to patterns of mobility perhaps better understood as varieties of migrant labor wherein longer-term residence becomes interspersed with periods of movement. 